\title{
Bat assemblages in conservation areas of a metropolitan region in Southeastern Brazil, including an important karst habitat
}

\author{
Talamoni, SA. ${ }^{a *}$, Coelho, DA. ${ }^{a}$, Dias-Silva, LH. ${ }^{a}$ and Amaral, AS. ${ }^{b}$ \\ aPrograma de Pós-graduação em Zoologia de Vertebrados, Departamento de Ciências Biológicas, Pontifícia Universidade \\ Católica de Minas Gerais - PUC Minas, Av. Dom José Gaspar, 500, CEP 30535-610, Belo Horizonte, MG, Brazil

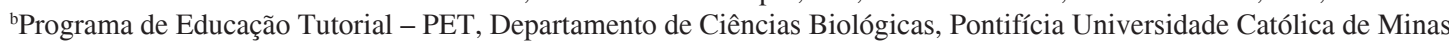 \\ Gerais - PUC Minas, Av. Dom José Gaspar, 500, CEP 30535-610, Belo Horizonte, MG, Brazil \\ *e-mail: talamoni@pucminas.br
}

Received October 31, 2011 - Accepted May 30, 2012 - Distributed May 31, 2013

(With 4 figures)

\begin{abstract}
Species richness and abundance of bats were studied in four nature reserves, including a karst area which has many potential rocky shelters for bats, such as caves and rock crevices. The reserves were located in the greater Belo Horizonte metropolitan area, one of the most populated regions of Brazil, within the Atlantic Forest, and Cerrado (Brazilian savanna) ecological domains. Bats were sampled using mist-nets and, in the karst area, also by active searches in shelters. A total of 1,599 bats were captured representing 30 species belonging to four families. There was little similarity among the four chiropteran faunas. The greatest species richness was found in the karst area with 22 species recorded whereas richness estimates in the other areas indicated the need for further studies. Two hundred and sixty-five individuals of 14 species were captured from 56 shelters. Most of the shelters were frequently used for diurnal roosts, and all the bats found belonged to the Phyllostomidae, with the exception of Myotis nigricans (Vespertilionidae), Nyctinomops laticaudatus (Molossidae) and Peropteryx macrotis (Emballonuridae). The sanguinivorous Desmodus rotundus was the most common species in the shelters. The results of this study demonstrate the importance of maintaining multiple protected areas to ensure a representative fauna of bats in a region characterized by a vegetation transition zone and with intense economic activity and high environmental impact. This study also demonstrates the importance of rock shelters for maintaining local bat richness and the importance of active searches for bats in their diurnal roosts for a more thorough sampling of the bat fauna at a given locality.
\end{abstract}

Keywords: Carste de Lagoa Santa, day roost sites, rock shelters, Serra do Rola Moça.

\section{Assembleias de morcegos em áreas de conservação de uma região metropolitana no sudeste do Brasil, incluindo um importante hábitat cárstico}

\begin{abstract}
Resumo
Neste estudo, a riqueza e a abundância de espécies de morcegos foram estudadas em quatro reservas naturais, incluindo uma área cárstica com muitas cavernas e fendas em rochas, que constituem abrigos rochosos potenciais para os morcegos. As reservas encontram-se dentro da região metropolitana de Belo Horizonte-MG, uma das mais povoadas do Brasil, e dentro dos domínios de Floresta Atlântica e do Cerrado. Os morcegos foram amostrados com redes de neblina (mist-nets) e, na área cárstica, também foi realizada busca ativa por morcegos em seus abrigos. Foram capturados 1.599 morcegos de 30 espécies, pertencentes a quatro famílias. Houve pouca similaridade entre as faunas de quirópteros analisadas. A maior riqueza foi encontrada na área cárstica, com 22 espécies registradas com redes de neblina e em seus abrigos; entretanto, estimativas de riqueza indicaram a necessidade de mais estudos nas outras áreas. Do total amostrado, 265 indivíduos de 14 espécies foram capturados em 56 abrigos. A maioria dos abrigos era ocupada no período diurno e de uso frequente; os morcegos presentes eram filostomídeos, exceto Myotis nigricans (Vespertilionidae), Nyctinomops laticaudatus (Molossidae) e Peropteryx macrotis (Emballonuridae). O hematófago Desmodus rotundus foi o mais frequente nos abrigos. O resultado deste estudo indica a importância da manutenção de diferentes áreas para a conservação dos quirópteros em região caracterizada como zona de transição vegetacional e com intensa atividade econômica e impacto ambiental. Este estudo demonstra também a importância dos abrigos rochosos para a riqueza local de espécies e a importância de busca ativa por morcegos em seus abrigos diurnos para uma amostragem mais efetiva da fauna local destes quirópteros.
\end{abstract}

Palavras-chave: Carste de Lagoa Santa, abrigos diurnos, abrigos rochosos, Serra do Rola-Moça. 


\section{Introduction}

Bats have a fundamentally important role in the maintenance of ecological processes in tropical and temperate zones. One factor considered crucial for certain species of bats is the presence of diurnal roosts (Kunz and Lumsden, 2005; Fenton et al., 2001; Mickleburgh et al., 2002). At the local level, bats are selective about their habitats and many have specific requirements for diurnal roosts (Wilson, 1997). Roosts can be natural, such as caves, rock crevices, holes in the ground, hollow trees, leaves, termite mounds, or the surfaces of tree trunks or they can be manmade structures, such as mines, tombs, buildings, bridges and other structures (Kunz and Lumsden, 2005).

Caves and rock shelters are especially important for bats because they provide protection from predators and harsh weather. These shelters provide greater microclimate stability compared with cavities in trees for example, and such stability is important for thermoregulation and development of infant bats (Bonaccorso et al., 1992; Vonhof and Barclay, 1996; Rodriguez-Durán and Soto-Centeno, 2003). In spite of this critical role that such shelters play in the lives of bats, knowledge on bats inhabiting caves in Brazil can be found in only a few studies (Trajano, 1985, 1995; Trajano and Moreira, 1991; Bredt et al., 1999; Trajano and Gimenez, 1998; Esbérard et al., 2005; Faria et al., 2006; Costa et al., 2010).

In karst areas, isolated karst outcrops have a great many potential shelters and may influence the local species richness of bats (Struebig et al., 2009), and the knowledge of species richness is the basis for any conservation strategy (Racey and Entwistle, 2005; Bernard et al., 2011). In the present study, we aimed to investigate the species richness and abundance of bats in an area in the Carste de Lagoa Santa, Minas Gerais, which is a karst area and has a large number of rock shelters (caves and crevices) potentially available to bats. A comparative analysis of species richness was made with nearby non-karst sites, in which there are no such rock structures. Inferences are also made about the most common feeding guilds present in the study areas.

\section{Material and Methods}

\subsection{Study areas}

The study was conducted in the state of Minas Gerais, Brazil, which is phytogeographically characterized by areas of Atlantic Forest, Cerrado (Brazilian savanna), and Campos Rupestres (rocky and scrubby grasslands at high altitudes) (IBGE, 2004). Its vegetation is distributed in a mosaic of predominantly semi-deciduous forests interspersed with grasslands. Bats were sampled in four locations in the greater metropolitan area of Belo Horizonte (Figure 1). The first study area, Fazenda Cauaia (Municipality of Matozinhos, $19^{\circ} 28^{\prime} \mathrm{S}, 44^{\circ} 00^{\prime} \mathrm{W}, 1048.6 \mathrm{ha}, 650 \mathrm{~m}$ above sea level), is part of the protected Área de Proteção Ambiental (APA) of Carste de Lagoa Santa (Carste LS). The Carste LS covers seven municipalities, and is considered the birthplace of paleontology, archeology, and caving in Brazil (BerbertBorn, 1998). The Fazenda Cauaia itself has $20 \%$ of its area under preservation and consists of rocky outcrops covered with semi-deciduous and deciduous forests, where the sampling took place. The seasonal semi-deciduous forest is typical of the surrounding and transitional areas between the rocky outcrops and deciduous forest, in which sinkholes and rocky outcrops occur (Brina, 1998).

The second area was the Parque Estadual Serra do Rola-Moça (PESRM) (Municipalities of Belo Horizonte, Nova Lima, Ibirité and Brumadinho, $20^{\circ} 01^{\prime}$ S, 435' $\mathrm{W}$; 3,941 ha), in the Serra do Rola-Moça, with elevations ranging from 1,100 to $1,400 \mathrm{~m}$ above sea level. The park comprises a mosaic of different floristic formations that include semi-deciduous forests, and cerrado vegetation, which is interspersed with campos rupestres, a flora typical of moderate altitudes (i.e., 1,000 to 1,800 m; Eiten, 1992). Bat sampling occurred in an area of approximately 600 ha at Área de Proteção Especial (APE) Mutuca at 1,130 m in the lower portion of the PESRM, covered mainly by semi-deciduous forest. The third study area was the Estação Ecológica de Fechos (EEFechos) (Municipality of Nova Lima, 20 $04^{\prime}$ S, 43 57' W, 602 ha, 1078 m above sea level). The EEFechos is an isolated fragment of secondary growth semi-deciduous forest, surrounded by intense human pressure due to the presence of large mining operations and residential condominiums. The areas EEFechos and PESRM are $9 \mathrm{~km}$ apart, and both are $60 \mathrm{~km}$ from Carste LS.

The fourth study area, Inhotim, is the nature reserve of the Instituto de Arte Contemporânea e Jardim Botânico

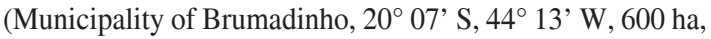
$752 \mathrm{~m}$ above sea level), consisting of second growth semi-deciduous forest and cerrado, and is surrounded by residential and mining areas. Along its western border, however, the Inhotim reserve contacts the preserved natural area of the water reservoir of Rio Manso, belonging to the water and sanitation company of Minas Gerais. The Rio Manso reserve $(9,200 \mathrm{ha})$ is comprised of secondary semi-deciduous forests and cerrado. Inhotim is $74 \mathrm{~km}$ from Carste LS, $28 \mathrm{~km}$ from EEFechos, and $37 \mathrm{~km}$ from PESRM.

\subsection{Bat sampling}

At all four study areas, bats were captured using five to eight mist-nets $(12 \times 2.5 \mathrm{~m}, 20 \mathrm{~mm}$ mesh), which were placed on trails and at forest margins and, in the case of the Fazenda Cauaia, the mist-nets were mounted close to, or directly on, rocky outcrops and between existing trails and forest margins. Nets were set before dusk, left open for six hours (6:00 PM-12:00 AM), and checked every 20 minutes. A sampling effort was calculated according to Straube and Bianconi (2002). Mist-net sampling was performed over 56 nights at Carste LS $\left(41,670 \mathrm{~m}^{2} . \mathrm{h}\right.$, between 2007 and 2008), 42 nights at Inhotim $\left(41,040 \mathrm{~m}^{2} . \mathrm{h}\right.$, in 2008), 37 nights at PESRM (16,545 $\mathrm{m}^{2}$.h, in 2003), and 37 nights at EEFechos $\left(16,545 \mathrm{~m}^{2} . h\right.$, in 2003). In all sampling areas, crescent and full moon nights were avoided. Voucher specimens for each species recorded 


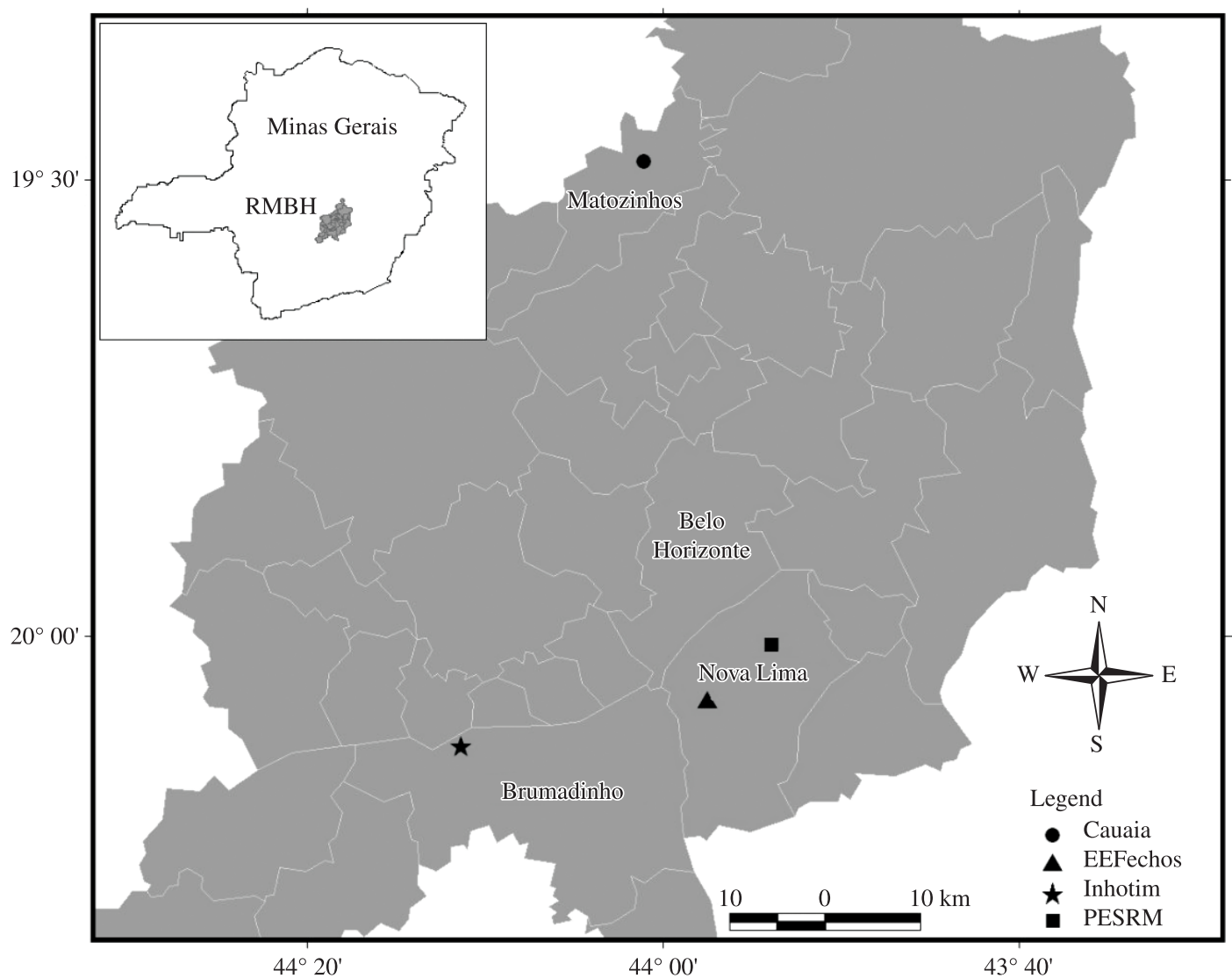

Figure 1. Sampling sites of bats in the metropolitan area of Belo Horizonte (RMBH) in the state of Minas Gerais, Brazil.

were deposited in the Coleção de Referência do Mestrado em Zoologia de Vertebrados, da Pontifícia Universidade Católica de Minas Gerais (PUC Minas), Belo Horizonte. Species were identified using the identification keys of Lim and Engstrom (2001), and Gregorin and Taddei (2002), plus assistance from experts (see Acknowledgements).

Throughout 2007-2008, active searches for bat roosts were conducted by two researchers for two days (8:00 AM-6:00 PM) monthly in an area of approximately 83 ha in Carste LS, totalling 26 days of searching. Searches for bats focused on rock crevices, caves, caverns, or any other place amongst the rocks that could serve as shelter. Only those localities with bats, or with signs that indicate the use of those sites by bats such as the presence of food remains or guano, were investigated. In situations where a roost was too high, or when it was not possible to identify the species in a roost, nets were placed over those openings in order to capture animals when leaving to forage.

\subsection{Data analysis}

Species richness for each of the four study areas was evaluated using rarefaction curves (Krebs, 1999; Gotelli and Colwell, 2001). Standardization was performed by generating rarefaction curves where the number of individuals of each species was plotted as a function of the cumulative number of samples. In this case, capture data were organized according to the accumulation of individuals of different species per sampling unit, defined as approximately $1,350 \mathrm{~m}^{2}$.h.

A Jackknife estimator of the first order was used in order to generate estimates of the expected richness for each study area from the sampling effort used (Hellmann and Fowler, 1999). Jackknife shows the average estimate of all samples and can estimate confidence intervals (95\%). The number of captures per unit of sampling effort was also used to analyze the similarity between the localities based on the index of association of Bray-Curtis (Bray and Curtis, 1957). This index is regardless of the measurement scale and does not assign resemblance to joint absences, i.e., it ignores cases where there are absences in joint samples (Krebs, 1999). Rarefaction curves were estimated using 100 randomizations. Both the curves and the similarity coefficients were obtained using EstimateS 8.0 (Colwell, 2006).

An analysis of trophic guilds present at each location, and the relative abundance of each, was also performed. 
Relative abundances were obtained by dividing the number of individuals of each species by the sampling effort, and then multiplying this result by $10^{3}$. The classification of species per guild was based on Kalko and Schnitzler (1998), and on Fonseca et al. (1996), and taxonomy and nomenclature follows Simmons (2005).

\section{Results}

A total of 1,599 bats representing 30 species belonging to four families were captured, of which 265 individuals were captured in 56 diurnal roosts (Tables 1 and 2). Phyllostomidae was the most common family, with 20 species, followed by Vespertilionidae, with six species. Frugivorous species of Artibeus and Platyrrhinus lineatus were the most dominant in terms of frequency of capture, followed by Desmodus rotundus (Table 1).

All bats sampled from roosts belonged to the Phyllostomidae, except for Nyctinomops laticaudatus, Myotis nigricans and Peropteryx macrotis (Table 2). Desmodus rotundus, together with Glossophaga soricina and $N$. laticaudatus were the most frequently found in rock roosts (Table 2 ). Shelters with $D$. rotundus were also occupied by the largest colonies (maximum 20 individuals). Accumulated guano was observed in most of the shelters (Table 2).

Based on the mist-netting data, Carste LS presented 17 species, followed by Inhotim and PESRM, both areas with 15 species. Estação Ecológica de Fechos had the lowest species richness with 12 species, but it also had the fewest number of sampling nights (Figure 2). Except for Carste LS, whose cumulative species discovery curve was close to the asymptote, the other sites still showed species discovery curves with a clear upward trajectory (Figure 2). When taking into account the total number of captures with both mist-nets and active searches in shelters, 22 species were recorded at Carste LS (Tables 1 and 2). The estimated expected richness (Jackknife 1), considering the upper limit of the $95 \%$ confidence interval, indicated an expected maximum number of 22 species of bats at Carste LS, 23 species at Inhotim, 24 at PESRM, and 17 at EEFechos (Figure 3). When comparing species richness among sites, taking into account only the equivalent number of sampling units (12), the greatest richness was at PESRM, followed by Inhotim, Carste LS, and then EEFechos (Figure 2).

There was little similarity among the four bat faunas, but PESRM and EEFechos were the closest (Table 3). Multiple trophic guilds were represented at each site, with five at Inhotim, and four at the other three sites (Figure 4). The bat fauna at all locations mainly consisted of frugivorous species, followed by fewer insectivores and nectarivores. The relative abundance of frugivores was also higher than the much lower relative abundances of the other guilds. In Carste LS, the sanguinivore was the second most abundant guild (Figure 4).

\section{Discussion}

It is noteworthy that the 30 species of bats recorded in this study all came from four sites within a major metropolitan area. This represents nearly $40 \%$ of the 77 species of bats officially known to occur in the state of Minas Gerais (Tavares et al., 2010). The greatest species richness occurred in the karst area (Carste LS), which is consistent with the species richness found in other areas with caves (Bredt et al., 1999; Esbérard et al., 2005). The estimated expected richness corresponded to the number of species recorded by mist-net captures and by searches in diurnal roosts in the Carste LS, indicating the importance of active searches for bats in their diurnal roosts for a more thorough sampling of the bat fauna at a given locality.

The most common species found in shelters in Carste LS was the sanguinivorous $D$. rotundus and the nectarivore G. soricina, as seen in other studies (Trajano, 1995; Bredt et al., 1999). Nyctinomops laticaudatus was the third most abundant species in the shelters, however this may be an underestimate because these individuals were found in cracks in rock walls, which made it difficult to obtain an accurate count of the number of individuals present. This species uses rock shelters and buildings (Nowak, 1994), however, there is no other record of this species using natural shelters in Brazil other than that recorded at Carste LS (Torquetti et al., 2011).

The record of species found in shelters confirms literature records on the species that often use caves or rock shelters in Brazil. In a study of a karst area in the Ribeira Valley, São Paulo, Trajano (1995) described several species commonly found in caves, including Carollia perspicillata, G. soricina, Anoura sp., M. nigricans, the phyllostomine Chrotopterus auritus and D. rotundus. In a study conducted in karst areas of the Federal District, Bredt et al. (1999) recorded D. rotundus, G. soricina, C. perspicillata and Mimon bennettii, among other less abundant species. These same species were also common in sandstone caves in São Paulo (Campanhã and Fowler, 1993). Esbérard et al. (2005) recorded Lonchorhina aurita and Lonchophylla dekeyseri as the most abundant species, among several other of the aforementioned species, in a karst area in the state of Goiás. It seems clear that some species are common cave dwellers, but further studies should be directed towards understanding the affinity of these species for this type of shelter. In our study, the vast majority of shelters showed an accumulation of guano, indicating constant use, but at present the factors that cause a species to choose certain types of diurnal roosts are poorly understood (Fenton et al., 2001).

The numerical predominance of individuals and species of phyllostomid bats, as observed in this study, is a common pattern in the Neotropics (Kalko and Handley, 2001; Bernard and Fenton, 2002; Falcão et al., 2003; Zortéa and Alho, 2008; Oprea et al., 2009; Alho et al., 2011). The most abundant species recorded with mist-nets were the fruit-eaters; Artibeus lituratus was the most numerous species at two of the sites, PESRM and EEFechos, while $P$. lineatus and A. planirostris were the most abundant species in Carste LS. Carollia perspicillata and Sturnira lilium were the most abundant species at Inhotim. Artibeus lituratus is considered a stratified forest generalist that 


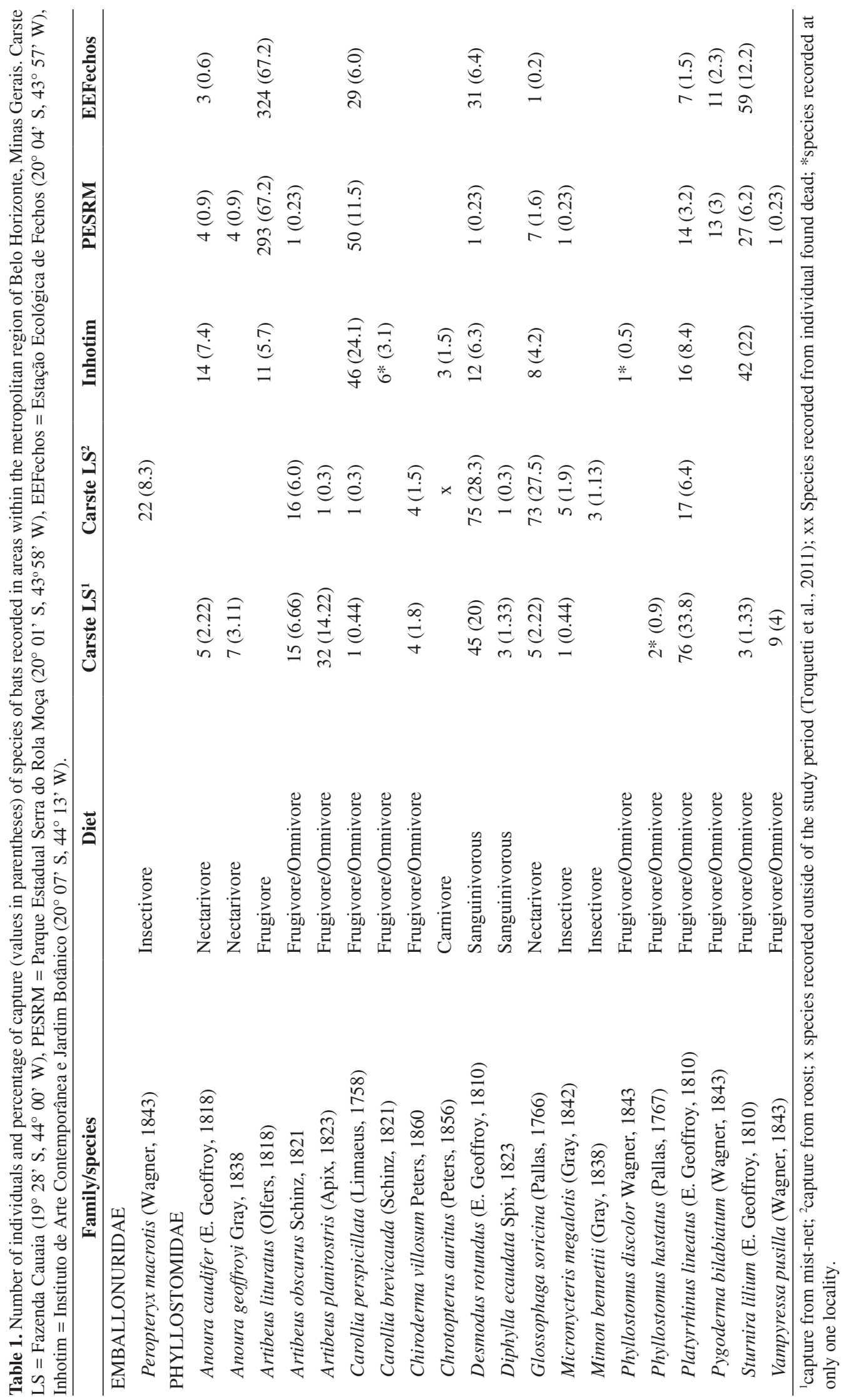


Talamoni, SA. et al.

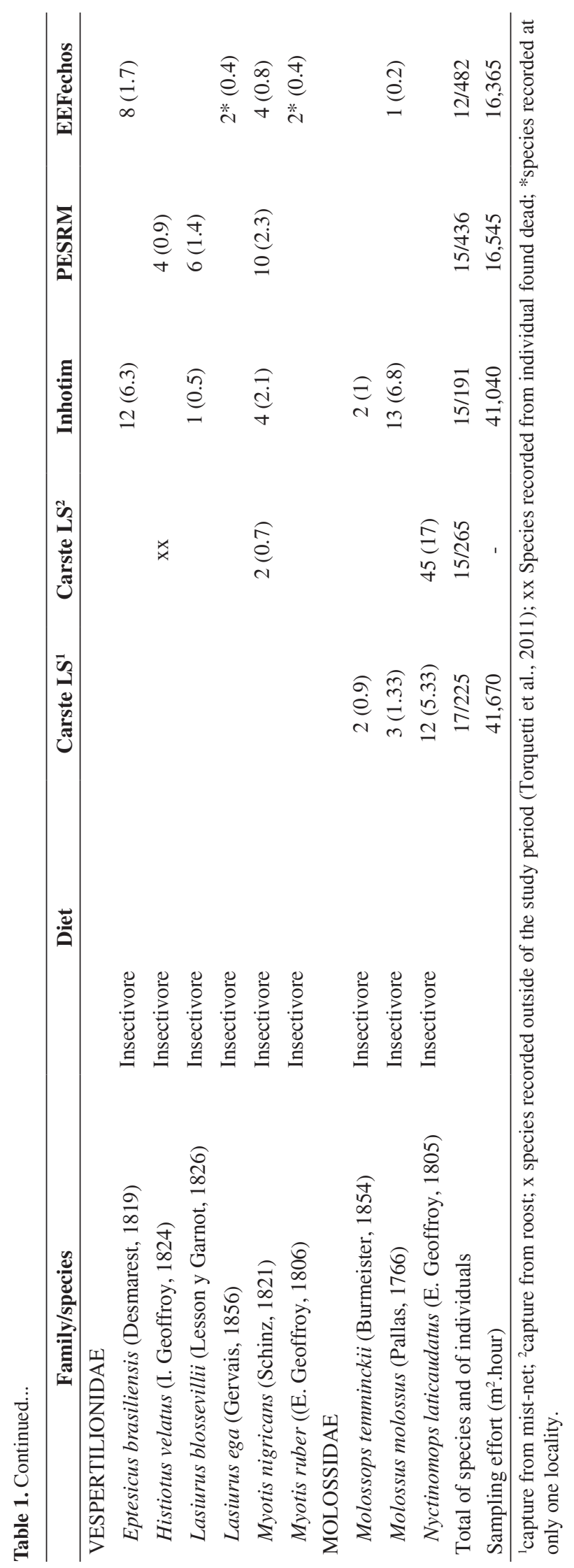


Table 2. Species of bats recorded in their diurnal roosts at the karst of Lagoa Santa, number of shelters and individuals (average, maximum and minimum) found in each shelter. Also shown is the percentage of shelters with an accumulation of guano. Data sampling from 2007 to 2008.

\begin{tabular}{|c|c|c|c|c|c|}
\hline Species & $\begin{array}{l}\text { Number of } \\
\text { shelters }\end{array}$ & $\begin{array}{l}\text { Number of individuals/shelter } \\
\text { Mean } \pm \text { SD }\end{array}$ & Min.-Max. & $\begin{array}{l}\text { Number of } \\
\text { individuals }\end{array}$ & $\begin{array}{l}\text { Shelter with } \\
\text { guano }(\%)\end{array}$ \\
\hline Anoura sp. & 1 & & & 2 & 0 \\
\hline A. obscurus & 1 & & & 16 & 100 \\
\hline A. planirostris & 1 & & & 1 & 0 \\
\hline C. perspicillata & 1 & & & 1 & 0 \\
\hline C. villosum & 2 & 1.5 & $1-3$ & 4 & 0 \\
\hline D. rotundus & 15 & $5 \pm 5,09$ & $1-20$ & 75 & 80 \\
\hline D. ecaudata & 1 & & & 1 & 0 \\
\hline G. soricina & 17 & 2.8 & $1-14$ & 73 & 0 \\
\hline M. megalotis & 1 & & & 5 & 100 \\
\hline M. bennettii & 1 & & & 3 & 100 \\
\hline M. nigricans & 2 & & & 2 & 0 \\
\hline N. laticaudatus & 1 & & & 45 & 100 \\
\hline P. macrotis & 8 & 2.75 & $1-4$ & 22 & 14,3 \\
\hline P. lineatus & 7 & 2.25 & $1-5$ & 17 & 25 \\
\hline
\end{tabular}

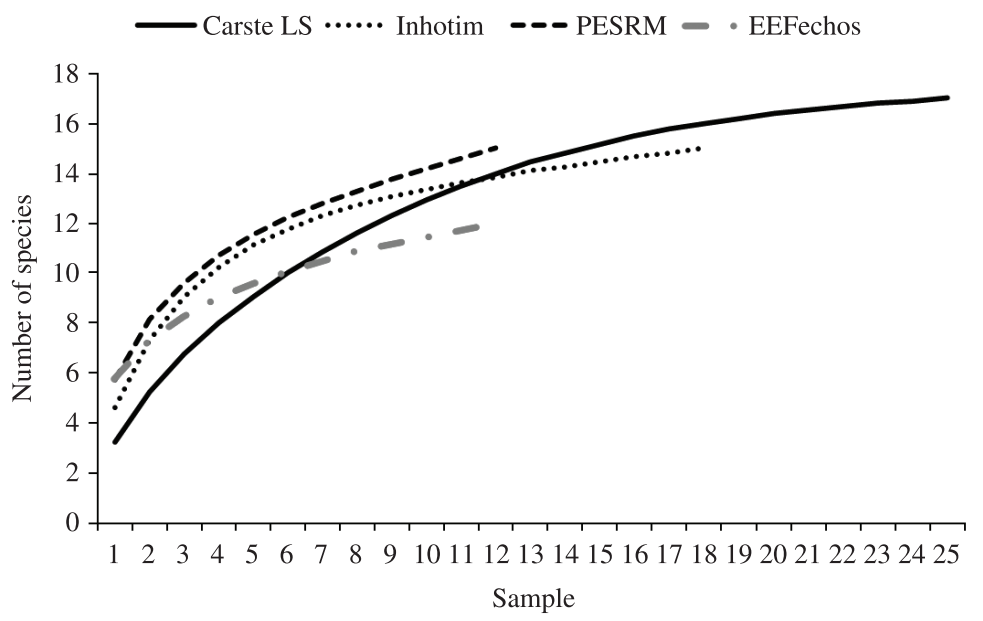

Figure 2. Rarefaction curves (Mao Tau) based on sampling units for bat species sampled at Carste de Lagoa Santa (Carste LS), Inhotim, Parque Estadual Serra do Rola Moça (PESRM), and Estação Ecológica de Fechos (EEFechos), in the metropolitan region of Belo Horizonte, Minas Gerais, between 2003 and 2008.

forages preferentially in the canopy, while $C$. perspicillata and $S$. lilium prefer to forage in the understory, and P. lineatus in both forest strata (Kalko and Handley, 2001). Artibeus lituratus and S. lilium have been identified as indicators of habitat disturbance, and are found commonly in deforested landscapes (Reis et al., 2003; Gorresen and Willig, 2004; Bobrowiec and Gribel, 2010). Moreover, the structure of phyllostomid assemblages can be influenced by differences in floral diversity, differences in types of secondary vegetation, food availability and vegetation structure (Mancina et al., 2007; Rex et al., 2008; Bobrowiec and Gribel, 2010). Therefore, only an analysis of diet and of the availability of resources can confirm whether the abundances of these species reflect real differences in partitioning of resources in the different vegetation strata in each study area.

Although the richness estimates in the present study have indicated the need for further studies at PESRM, EEFechos and Inhotim, the lower richness observed in these areas may be an indication of impoverished assemblages. This result, however, could also be an artifact of the use of ground-level mist-nets in areas of different vegetative structure, in addition to other differing elements of the 


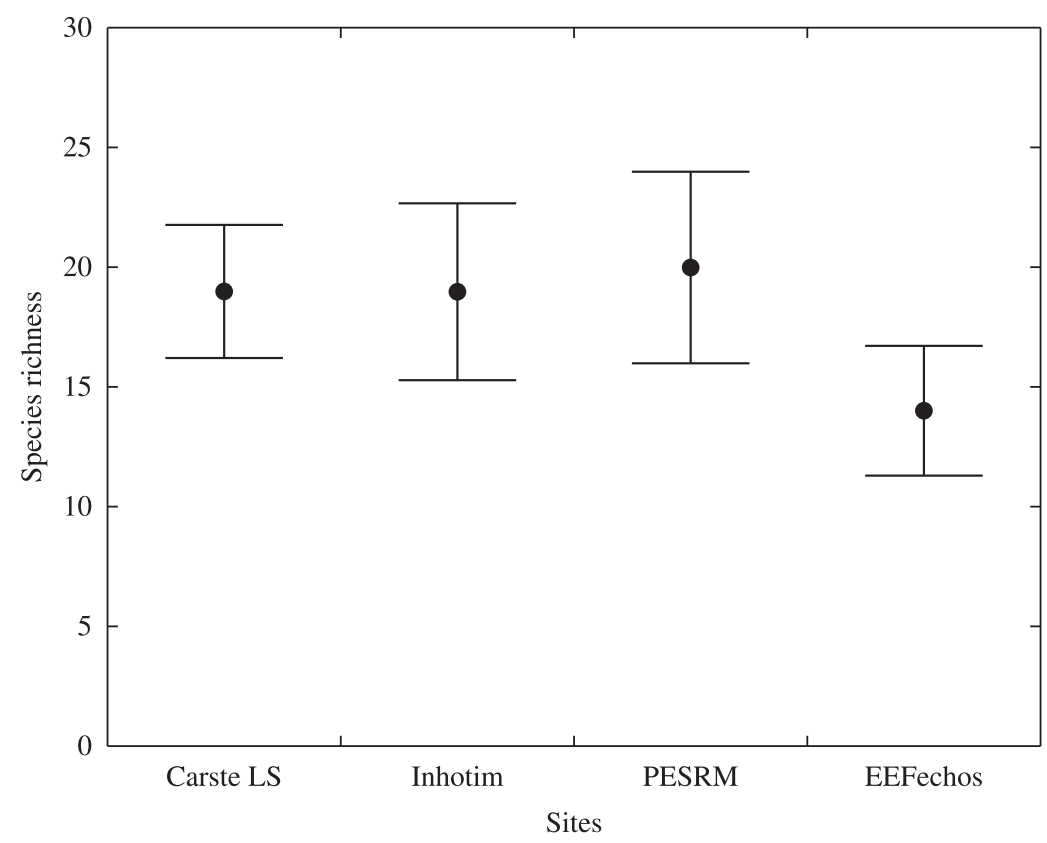

Figure 3. Estimated species richness of bats based on the estimator Jackknife 1 for Carste de Lagoa Santa (Carste LS), Inhotim, Parque Estadual Serra do Rola Moça (PESRM), and Estação Ecológica de Fechos (EEFechos), in the metropolitan region of Belo Horizonte, Minas Gerais, sampled between 2003 and 2008.
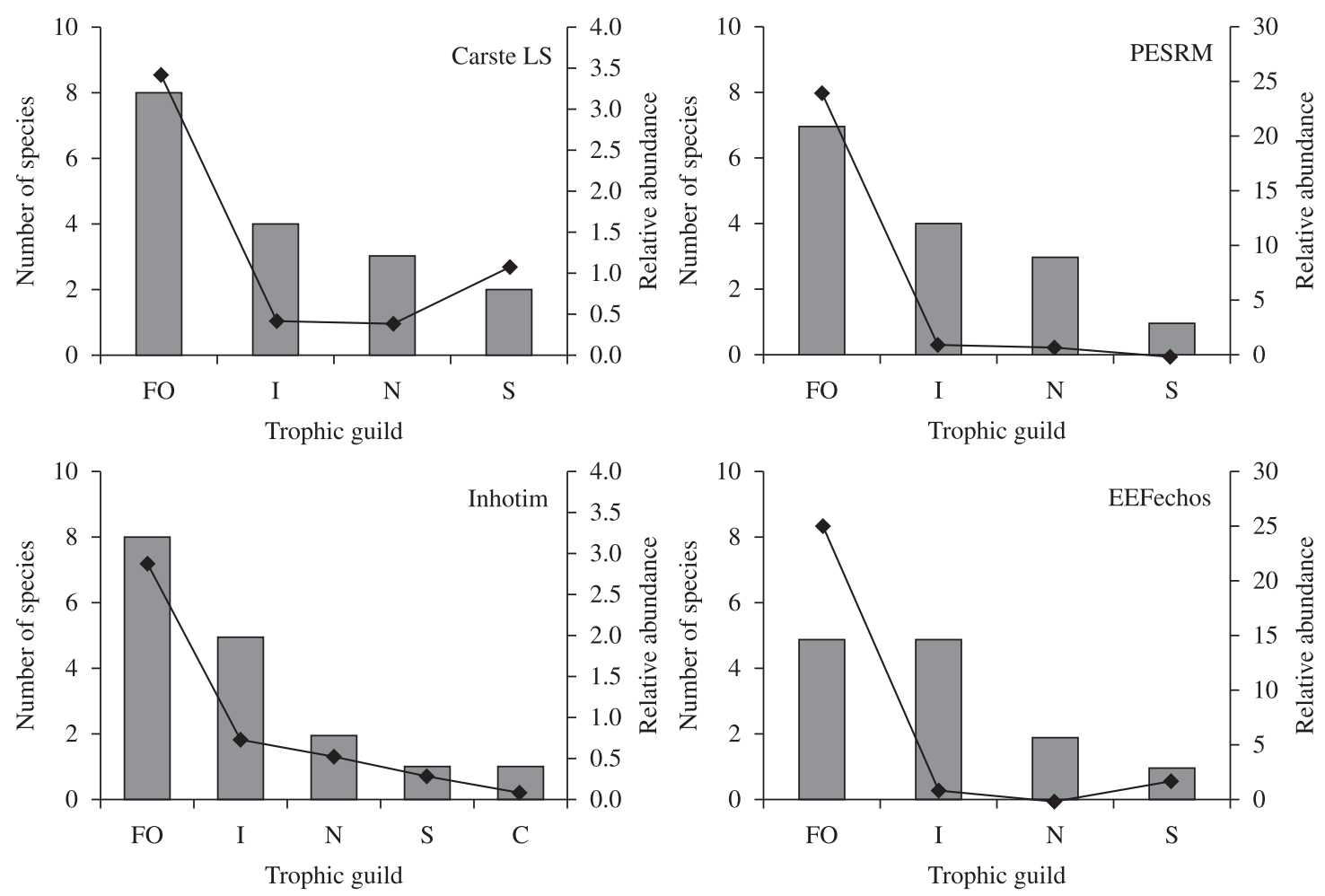

Figure 4. Trophic guilds (column) and relative abundance (line) of bats recorded in the Carste de Lagoa Santa (Carste LS), Inhotim, Parque Estadual Serra do Rola Moça (PESRM) and Estação Ecológica de Fechos (EEFechos), in the metropolitan region of Belo Horizonte, Minas Gerais, between 2003 and 2008. Legend: FO= Frugivore/Omnivore; I = insectivore; $\mathrm{N}=$ Nectarivore; $\mathrm{S}=$ Sanguinivorous; $\mathrm{C}=$ Carnivore. 
Table 3. Coefficients of similarity (Bray-Curtis) between the number of species of bats at four sites in the state of Minas Gerais, Brazil. Carste LS = Carste de Lagoa Santa, Inhotim = Instituto de Arte Contemporânea e Jardim Botânico, PESRM = Parque Estadual Serra do Rola-Moça, EEFechos = Estação Ecológica de Fechos.

\begin{tabular}{lccc}
\hline & Inhotim & PESRM & EEFechos \\
\hline Carste LS & 0.225 & 0.096 & 0.145 \\
Inhotim & & 0.336 & 0.328 \\
PESRM & & & 0.801 \\
\hline
\end{tabular}

landscape of each area. Inhotim was indeed the location with the highest capture frequencies of aerial insectivores. This result may be related to the presence of bodies of water in the area which would favor the activity of aerial foraging insectivores, although the difficulty of sampling individuals of this trophic guild, with their facility to detect mist-nets and forage at high altitudes, is well known (Fenton and Griffin, 1997; Kalko and Handley, 2001).

It is important to realize that at present, the factors influencing the distribution and species richness of bats are still poorly understood (Alho et al., 2011; Fahr and Kalko, 2011; Mehr et al., 2011). According to recent studies, land use, habitat complexity, and heterogeneity along biome gradients have been identified as important for determining the structure of bat assemblages at both local and regional scales (Mancina et al., 2007; Fahr and Kalko, 2011; Mehr et al., 2011).

Most of the species recorded in the study region have a widespread distribution, covering more than three of the predominant biomes in Brazil (Marinho-Filho and Sazima, 1998). Four species, however, have more restricted distributions. Myotis ruber occurs in the Atlantic Forest and Caatinga, Pygoderma bilabiatum occurs in the Atlantic Forest, Cerrado and Pantanal, and Vampyressa pusilla and Histiotus velatus are known to occur in the Atlantic Forest and Cerrado (Marinho-Filho and Sazima, 1998; Falcão et al., 2003; Sbragia and Pessôa, 2008).

Some species were recorded in only one of the four sampled areas such as the phyllostomines Phyllostomus discolor, P. hastatus, Chrotopterus auritus, Mimon bennettii, and the insectivores Peropteryx macrotis (Emballonuridae), and Myotis ruber (Vespertilionidae). Interestingly, the phyllostomines and some insectivores have been considered more sensitive to environmental disturbances (Fenton et al., 1992; Schulze et al., 2000; Bobrowiec and Gribel, 2010). One such species, $M$. ruber, is classified by the IUCN as near threatened (Barquez and Diaz, 2008) and is listed as vulnerable in Brazil (Machado et al., 2005). The record of these species in unique localities, and the record of $M$. ruber at EEFechos, a small fragment, demonstrates the importance of maintaining multiple protected areas to ensure a representative fauna of bats in a region characterized by a zone of contact between the Cerrado and Atlantic Forest ecological domains, a fact confirmed by the low similarity of species among the studied areas. Furthermore, the region is marked by intense economic activity and high environmental impact, which reinforces the need to preserve these areas. This study also demonstrates the importance of rock shelters for maintaining the local richness of bats in a karst area, and the importance of active searches for bats in their diurnal roosts for a more through sampling of the bat fauna at a given locality.

Acknowledgements - We would like to thank Denis Gatti and Eduardo Pupo Nogueira for help with collecting bats, Fabio C. Falcão for comments, Valeria C. Tavares for identifying some individual specimens, and Erik Wild for proofreading the English text. The manuscript was improved by valuable comments from two anonymous reviewers. We gratefully acknowledge Mr. José Hein for all his support and other logistical assistance while sampling at Fazenda Cauaia; the Sanitation Company of Minas Gerais (COPASA) for logistical support for sampling at PESRM and EEFechos; and the Institute of Contemporary Art and Botanical Garden (Inhotim) for their support. Sampling was made possible with licenses granted by IBAMA and ICMBio. LHD was awarded a scholarship (BIC) from FAPEMIG. This study was funded by FAPEMIG and FIP PUC Minas.

\section{References}

ALHO, CJR., FISCHER, E., OLIVEIRA-PISSINI, LF. and SANTOS, CF., 2011. Bat-species richness in the Pantanal floodplain and its surrounding uplands. Brazilian Journal of Biology, vol. 71, no. 1 Supplement, p. 311-320. PMid:21537604.

BARQUEZ, R. and DIAZ, M., 2008. Myotis ruber. In International Union for Conservation of Nature. IUCN Red List of Threatened Species. version 2011.1. Available from: <http://www.iucnredlist. org>. Access in: 28 Aug. 2011.

BERBERT-BORN, M., 1998. Carste de Lagoa Santa, MG. Berço da Paleontologia e da Espeleologia brasileira. Série Sítios Geológicos e Paleontológicos do Brasil, vol. 5, p. 415-430.

BERNARD, E. and FENTON, MB., 2002. Species diversity of bats (Mammalia: Chiroptera) in forest fragments, primary forest, and savannas in Central Amazonia, Brazil. Canadian Journal of Zoology, vol. 80, p. 1124-1140. http://dx.doi.org/10.1139/z02-094

BERNARD, E., AGUIAR, LMS. and MACHADO, RB., 2011. Discovering the Brazilian bat fauna: a task for two centuries? Mammal Review, vol. 41, no. 1, p. 23-39. http://dx.doi.org/10.1111/ j.1365-2907.2010.00164.x

BONACCORSO, FJ., ARENDS, A., GENOUD, M., CANTONI, D. and MORTON, T., 1992. Thermal ecology of mustached and ghost-faced bats (Mormoopidae) in Venezuela. Journal of Mammalogy, vol. 73, p. 365-378. http://dx.doi.org/10.2307/1382071

BOBROWIEC, PED. and GRIBEL, R., 2010. Effects of different secondary vegetation types on bat community composition in Central Amazonia, Brazil. Animal Conservation, vol. 13, p. 204216. http://dx.doi.org/10.1111/j.1469-1795.2009.00322.x

BRAY, JR. and CURTIS, JT., 1957. An ordination of the upland forest communities of southern Wisconsin. Ecological Monographs, vol. 27, p. 325-349. http://dx.doi.org/10.2307/1942268

BREDT, A., UIEDA, W. and MAGALHÃES, ED., 1999. Morcegos cavernícolas da região do Distrito Federal, centrooeste do Brasil (Mammalia, Chiroptera). Revista Brasileira de 
Zoologia, vol. 16, no. 3, p. 731-770. http://dx.doi.org/10.1590/ S0101-81751999000300012

BRINA, AE., 1998. Aspectos da dinâmica da vegetação associada a afloramentos calcários na APA Carste de Lagoa Santa, MG. Belo Horizonte: Universidade Federal de Minas Gerais. Dissertação de Mestrado e Ecologia e Manejo de fauna Silvestre.

CAMPANHÃ, RAC. and FOWLER, HG., 1993. Roosting assemblages of bats in arenitcs caves in remnant fragments of Atlantic Forest in Southern, Brazil. Biotropica, vol. 25, no. 3, p. 362-365. http://dx.doi.org/10.2307/2388798

COLWELL, RK., 2006. Estimate $S$ : Statistical estimation of species richness and shared species from samples. version 8 . Available from: <http://purl.oclc.org/estimates $>$.

COSTA, LM., LOURENÇO, EC., ESBÉRARD, CEL. and SILVA, RM., 2010. Colony size, sex ratio and cohabitation in roosts of Phyllostomus hastatus (Pallas) (Chiroptera: Phyllostomidae). Brazilian Journal of Biology, vol. 70, no. 4, p. 1047 - 1053. PMid:21180912. http://dx.doi.org/10.1590/ S1519-69842010000500019

EITEN, G., 1992. Natural Brazilian Vegetation Types and their Causes. Anais da Academia Brasileira de Ciências, vol. 64, p. 35-65.

ESBÉRARD, CEL., MOTTA, JA. and PERIGO, C. 2005. Morcegos cavernícolas da Área de Proteção Ambiental (APA) Nascentes do Rio Vermelho, Goiás. Revista Brasileira de Zoociências, vol. 7, p. 311-325.

FAHR, J. and KALKO, EKV., 2011. Biome transitions as centres of diversity: habitat heterogeneity and diversity patterns of West African bat assemblages across spatial scales. Ecography, vol. 34, p. 177-195. http://dx.doi.org/10.1111/j.1600-0587.2010.05510.x

FALCÃO, F., RABELO, V. and TALAMONI, SA., 2003. Structure of a bat assemblage (Mammalia, Chiroptera) in Serra do Caraça reserve, South-east, Brazil. Revista Brasileira de Zoologia, vol. 20, no. 2, p. 347-350. http://dx.doi.org/10.1590/ S0101-81752003000200027

FARIA, D., SOARES-SANTOS, B. and SAMPAIO, E., 2006. Bats from the Atlantic rainforest of southern Bahia, Brazil. Biota Neotropica, vol. 6. Available from: <http://www.biotaneotropica. org.br/v6n2/pt/abstract?inventory+bn02406022006>. http://dx.doi. org/10.1590/S1676-06032006000200022

FENTON, MB. and GRIFFIN, DR., 1997. High altitude pursuit of insects by echolocating bats. Journal of Mammalogy, vol. 78, p. 247-250. http://dx.doi.org/10.2307/1382658

FENTON, MB., ACHARYA, L., AUDET, D., HICKEY, MBC., MERRIMAN, C., OBRIST, MK. and SYME, DM., 1992. Phyllostomid bats as indicators of habitat disruption in the Neotropics. Biotropica, vol. 24, no. 3, p. 440-446. http://dx.doi. org/10.2307/2388615

FENTON, MB., BERNARD, E., BOUCHARD, S., HOLLIS, L., JOHNSTON, DS., LAUSEN, CL., RATCLIFFE, JM., RISKIN, DK., TAYLOR, JR. and ZIGOURIS, J., 2001. The Bat Fauna of Lamanai, Belize: Roosts and Trophic Roles. Journal of Tropical Ecology, vol. 17, no. 4, p. 511-524.

FONSECA, GAB., HERMANN, G., LEITE, YLR., MITTERMEIER, RA., RYLANDS, AB. and PATTON, JL., 1996. Lista Anotada dos Mamíferos do Brasil. Belo Horizonte: Conservation International. 38 p. Occasional Papers in Conservation Biology, No. 4.

GORRESEN, PM. and WILLIG, MR., 2004. Landscape responses of bats to habitat fragmentation in Atlantic Forest of Paraguay.
Journal of Mammalogy, vol. 85, no. 4, p. 688-697. http://dx.doi. org/10.1644/BWG-125

GOTELLI, N. and COLWELL, RK., 2001. Quantifying biodiversity: procedures and pitfalls in the measurement and comparison of species richness. Ecology Letters, vol. 4, p. 379-391. http://dx.doi. org/10.1046/j.1461-0248.2001.00230.x

GREGORIN, R. and TADDEI, VA., 2002. Chave artificial para identificação de molossídeos brasileiros (Mammalia, Chiroptera). Mastozoologia Neotropical, vol. 9, no. 1, p. 13-32.

HELLMANN, JJ. and FOWLER, GW., 1999. Bias, precision, and accuracy of four measures of species richness. Ecological Applications, vol. 9, p. 824-834. http://dx.doi.org/10.1890/10510761(1999)009[0824:BPAAOF]2.0.CO;2

Instituto Brasileiro de Geografia e Estatística - IBGE. 2004. Mapa de vegetação do Brasil, escala 1:5000 000. IBGE.

KALKO, EK. and SCHNITZLER, H., 1998. How echolocating bats approach and acquire food. In KUNZ, TH. and RACEY, PA. (Ed.). Bat, Biology and Conservation. Washington: Smithsonian Institution Press. p. 197-204.

KALKO, EK. and HANDLEY, CO., 2001. Neotropical bats in the canopy: diversity, community structure, and implication for conservation. Plant Ecology, vol. 153, p. 319-333. http://dx.doi. org/10.1023/A:1017590007861

KREBS, CJ., 1999. Ecological Methodology. 2nd ed. AddisonWelsy Educational Publishers, Inc.

KUNZ, TH. and LUMSDEN, LF., 2005. Ecology of cavity and foliage roosting bats. In KUNZ, TH. and FENTON, MB. Bat Ecology. Chicago: The University of Chicago Press. p. 779.

LIM, BK. and ENGSTROM, MD., 2001. Species diversity of bats (Mammalia: Chiroptera) in Iwokrama Forest, Guyana, and the Guianan subregion: implications for conservation. Biodiversity and Conservation, vol. 10, p. 613-657. http://dx.doi. org/10.1023/A:1016660123189

MANCINA, CA., GARCIA-RIVERA, L. and CAPOTE, RT., 2007. Habitat use by phyllostomid bat assemblages in secondary forests of the Sierra del Rosario Biosphere Reserve, Cuba. Acta Chiropterologica, vol. 9, p. 203-218. http://dx.doi.org/10.3161/17335329(2007)9[203:HUBPBA]2.0.CO;2

MACHADO, ABM., MARTINS, CS. and DRUMMOND, GM., 2005. Lista da Fauna Brasileira Ameaçada de Extinção: incluindo as espécies quase ameaçadas e deficientes em dados. Belo Horizonte: Fundação Biodiversitas.

MARINHO-FILHO, J. and SAZIMA, I., 1998. Brazilian bats and conservation biology; a First Survey. In KUNZ, TH. and RACEY, PA., Ed. Bat, Biology and Conservation. Washington: Smithsonian Inst. Press. p. 282-294.

MEHR, M., BRANDL, R., HOTHORNC, T., DZIOCKD, F., FÖRSTERE, B. and MÜLLER, J., 2011. Land use is more important than climate for species richness and composition of bat assemblages on a regional scale. Mammalian Biology, vol. 76, p. 451-460. http://dx.doi.org/10.1016/j.mambio.2010.09.004

MICKLEBURGH, SP., HUTSON, AM. and RACEY, PA., 2002. A review of the global conservation status of bats. Oryx, vol. 36, p. 18-34.

NOWAK, RM., 1994. Walker's Bats of the World/Ronald M. Nowak. 1994. Baltimore: The John Hopkins University Press. 
OPREA, MAB, ESBÉRARD, CEL., VIEIRA, TB., MENDES, P., PIMENTA, VT., BRITO, D. and DITCHFIELD, AD., 2009. Bat community species richness and composition in a restinga protected area in Southeastern Brazil. Brazilian Journal of Biology, vol. 69, no. 4, p. 1073-1079. PMid:19967177.

RACEY, PA. and ENTWISTLE, AC., 2005. Conservation ecology of bats. In KUNZ, TH. and FENTON, MB. Ed. Bat Ecology. Chicago: The University of Chicago Press.

REIS, NR., BARBIERI, MLS., LIMA, IP. and PERACCHI, AL., 2003. O que é melhor para manter a riqueza de espécies de morcegos (Mammalia, Chiroptera): um fragmento florestal grande ou vários fragmentos de pequeno tamanho? Revista Brasileira de Zoologia, vol. 20, no. 2, p. 225-230. http://dx.doi.org/10.1590/ S0101-81752003000200009

REX, K., KELM, DH., WIESNER, K., KUNZ, TH. and VOIGT, CC., 2008. Species richness and structure of three Neotropical bat assemblages. Biological Journal of the Linnean Society, vol. 94, p. 617-629. http://dx.doi.org/10.1111/j.1095-8312.2008.01014.x

RODRIGUEZ-DURÁN, A. and SOTO-CENTENO, JA., 2003. Temperature selection by tropical bats roosting in caves. Journal of Thermal Biology, vol. 28, p. 465-468.

SBRAGIA, IA. and PESSÔA, LM., 2008. New record of a vulnerable bat, Myotis ruber (E. Geoffroy, 1806) (Chiroptera: Vespertilionidae) in the Caatinga biome, northeastern Brazil. Mammalian Biology, vol. 73, p. 233-237. http://dx.doi.org/10.1016/j. mambio.2007.02.009

SCHULZE, MD., SEAVY, NE. and WHITACRE, DF., 2000. A comparison of the Phyllostomid bat assemblages in undisturbed Neotropical forest and in forest fragments of a slash-and-burn farming mosaic in Petén, Guatemala. Biotropica, vol. 32, no. 1, p. $174-184$.

SIMMONS, NB., 2005. Order Chiroptera. In WILSON, DE. and REEDER, DM. Ed. Mammal Species of the World: A Taxonomic and Geographic Reference. 3rd ed. Baltimore: John Hopkins University Press. p. 312-529.

STRAUBE, FC. and BIANCONI, GV., 2002. Sobre a grandeza e a unidade utilizada para estimar esforço de captura com utilização de redes-de-neblina. Chiroptera Neotropical, vol. 8, no. $1-2$, p. $150-152$.

STRUEBIG, MJ., KINGSTON, T., ZUBAID, A., LE COMBER, SC., MOHD-ADNAN, A., TURNER, A., KELLY, J., BOZEK, M., ROSSITER, SJ., 2009. Conservation importance of limestone karst outcrops for paleotropical bats in a fragment landscape. Biological Conservation, vol. 142, p. 2089-2096. http://dx.doi. org/10.1016/j.biocon.2009.04.005

TAVARES, VC., AGUIAR, LMS., PERINI, FA., FALCÃO, FC. and GREGORIN, R., 2010. Bats of the state of Minas Gerais, southeastern Brazil. Chiroptera Neotropical, vol. 16, no. 1 , p. 675-705.

TORQUETTI, CG., CARMO, SSA. and TALAMONI, SA., 2011. Morcegos cavernícolas no Carste de lagoa Santa. Chiroptera Neotropical, vol. 17, no. 1 Supplement, p. 126-131.

TRAJANO, E., 1985. Ecologia de populações de morcegos cavernícolas em uma região carstica do Sudeste do Brasil. Revista Brasileira de Zoologia, vol. 2, no. 5, p. 255-320. http://dx.doi. org/10.1590/S0101-81751984000100001

-, 1995. Protecting caves for the bats or bats for the caves? Chiroptera Neotropical, vol. 1, no. 2, p. 19-22.

TRAJANO, E. and GIMENEZ, EA., 1998. Bat community in a cave from eastern Brazil, including a new record of Lionycteris (Phyllostomidae, Glossophaginae). Studies on Neotropical Fauna and Environment, vol. 33, p. 69-75. http://dx.doi.org/10.1076/ snfe.33.2.69.2156

TRAJANO, E. and MOREIRA, JRA., 1991. Estudo da fauna de cavernas da Província Espeleológica Arenítica Altamira-Itaituba, PA. Revista Brasileira de Biologia, vol. 51, no. 1, p. 13-29.

VONHOF, MF. and BARCLAY, RMR., 1996. Roost-site selection and roosting ecology of forest-dwelling bats in southern British Columbia. Canadian Journal of Zoology, vol. 74, p. 1797-1805. http://dx.doi.org/10.1139/z96-200

WILSON, DE., 1997. Bats in question: The Smithsonian Answer Book. Washington: The Smithsonian Institution. p. 168.

ZORTÉA, M. and ALHO, CJR., 2008. Bat diversity of a Cerrado habitat in central Brazil. Biodiversity and Conservation, vol. 17, p. 791-805. http://dx.doi.org/10.1007/s10531-008-9318-3 